\title{
Report on deep-sea bonelliids (Echiura) from the East Equatorial Atlantic Ocean
}

\author{
Ramlall BISESWAR \\ School of Biological and Conservation Sciences, \\ University of KwaZulu-Natal (Westville Campus), \\ Private Bag X54001, Durban 4000 (Republic of South Africa) \\ biseswar@ukzn.ac.za
}

KEY WORDS

Echiura,

Bonelliidae, deep-sea,

East Equatorial Atlantic,
Biseswar R. 2010. - Report on deep-sea bonelliids (Echiura) from the East Equatorial Atlantic Ocean. Zoosystema 32 (1): 139-154.

\section{ABSTRACT}

This report contains descriptions of 14 species of deep-sea bonelliids of which five are indeterminate species. The specimens were collected during the ZAIANGOBIOL 2 and BIOZAIRE 1, 2 and 3 cruises that were undertaken in the East Equatorial Atlantic Ocean between August 2000 and January 2004. This report gives additional information on some of the species that were described from damaged or incomplete specimens by previous authors. One bonelliid female in the collection, which is incomplete, has been tentatively assigned to the genus Sluiterina. The gonoduct of this specimen has an accessory sac opening into it. To date, such a gonoduct has not been described in any other bonelliid species. It is very likely that additional material from that region in the future may reveal that this specimen belongs to a new genus. Another female which is also incomplete has been assigned to the genus Bruunellia. This specimen has an anal vesicle which differs markedly from those described so far in all the other bonelliid species. Detailed studies on additional specimens from that region in the future may indicate that it belongs to a new species. All the species in this report have been recorded previously either from the subtropical or from the North-East Atlantic. The discovery of these bonelliids in the East Equatorial Atlantic Ocean, south of $5^{\circ} \mathrm{S}$ latitude, are new records for this region and now extends the geographical ranges of the species southwards. 


\section{MOTS CLÉS \\ Echiura, \\ Bonelliidae, \\ eaux profondes, \\ Atlantique équatorial oriental, nouvelles mentions.}

\begin{abstract}
RÉSUMÉ
Rapport sur les Bonelliidae (Echiura) d'eaux profondes de l'Atlantique équatorial oriental.

Ce travail contient la description de 14 espèces dont cinq indéterminées de Bonelliidae d'eaux profondes. Les spécimens ont été récoltés durant les campagnes ZAIANGO-BIOL 2 et BIOZAIRE 1, 2 et 3 qui ont eu lieu dans l'Océan Atlantique équatorial oriental entre août 2000 et janvier 2004. Nous donnons des informations supplémentaires sur des espèces décrites à partir de spécimens endommagés ou incomplets par des auteurs antérieurs. Une femelle Bonelliidae incomplète a été assignée au genre Sluiterina de façon incertaine. Le gonoducte de ce spécimen possède un sac accessoire. À ce jour, un tel gonoducte n'a été décrit dans aucune autre espèce de Bonelliidae. Il est très probable que du matériel additionnel de cette région révèle que ce spécimen appartient à un nouveau genre. Une autre femelle, qui est aussi incomplète, a été attribuée au genre Bruunellia. Ce spécimen possède une vésicule anale qui diffère franchement de celles déjà décrites d'autres Bonelliidae. Des études détaillées sur des spécimens additionnels de cette région dans le futur pourraient indiquer qu'il s'agit d'une nouvelle espèce. Toutes les espèces de ce travail ont déjà été mentionnées de l'Atlantique subtropical ou du nord-est de l'Atlantique. La découverte de ces Bonelliidae dans l'Atlantique équatorial oriental, au sud de la latitude $5^{\circ} \mathrm{S}$, constitue de nouvelles mentions pour cette région et étend vers le sud la répartition de ces espèces.
\end{abstract}

\section{INTRODUCTION}

This report is based on deep-sea echiurans (phylum Echiura) collected during the ZAIANGO-BIOL 2 and BIOZAIRE 1, 2 and 3 cruises that were undertaken by the Ifremer biological team between August 2000 and January 2004. These cruises were part of a general study programme in the East Equatorial Atlantic Ocean in the framework of a scientific and technical cooperation between Total-Fina-Elf and Ifremer. The ZAIANGO-BIOL 2 cruise was undertaken at two localities of the Angolan margin, one in the vicinity of coral mounds at a depth of about $350 \mathrm{~m}$ and the other at a depth of $1350 \mathrm{~m}$.

The scientific objectives of these cruises were to: 1) describe the benthic communities in terms of their composition, density and biomass (bacteria, meiofauna, macrofauna and megafauna); 2) characterise the chemical composition of the surface sediment; 3) evaluate the spatial distribution of the communities in relation to the chemical features of their environment; 4) evaluate the dynamics of the sediment community through an experimental approach; 5) evaluate the temporal variability of the vertical carbon flux and of the physical characteristics of the environment in the benthic boundary layer; and 6) evaluate the relations between the two types of ecosystems.

The influence of the Zaire inputs on the communities, including their temporal variations in terms of carbon flux, hydrodynamism and chemical parameters was tested at two stations at a depth of $4000 \mathrm{~m}$, one next to the Zaire channel (ZD) and the other (ZC) $250 \mathrm{~km}$ south of the channel. Chemosynthetic based ecosystems were studied mainly at two stations, one at around $3000 \mathrm{~m}$ depth near the Zaire mouth (Regab), and the second one on the Gabon margin at around $500 \mathrm{~m}$ depth (Guiness). 
The exploration of the different ecosystems was conducted mainly using the ROV Victor which allows for the sampling of water, sediment and fauna and also for the measurement of physical and chemical parameters.

Sampling of megafauna was carried out using a bottom trawl while sampling of macrofauna and meiofauna was done using an USNEL box corer and a multicorer respectively.

During sampling of the benthic fauna, information about the biological characteristics of the different species was also recorded.

The echiuran specimens of this report were received through the courtesy of Joëlle Galeron of the CENTOB, Ifremer, Centre de Brest for the purpose of identification. All the specimens in the collection belong to the family Bonelliidae and include nine known species of deep-sea bonelliids and five species indeterminate. All the species in this report have been recorded previously from the subtropical and North-East Atlantic by DattaGupta (1981) and Biseswar (1992, 2005, 2006). The discovery of these bonelliids from the East Equatorial Atlantic Ocean are new records for this region and now extends the geographical ranges of the species.

The nomenclature used here follows that of Stephen \& Edmonds (1972) and Nishikawa (1998).

All the specimens in this report have been deposited in the Muséum national d'Histoire naturelle, Paris (MNHN).

\section{SYSTEMATICS}

Family BONELLIIDAE Lacaze-Duthiers, 1958 Genus Alomasoma Zenkevitch, 1958

Alomasoma belyaevi Zenkevitch, 1964 (Fig. 1A, B)

Material eXamined. - East Equatorial Atlantic Ocean. Gulf of Guinea, BIOZAIRE 3, CP 10, stn ZB-D, 5'50.6300'S, 8²0.0600'E, 3977 m, 19.XII.2003, 1 ․ CP 11, stn ZB-D, $05^{\circ} 50.5840^{\prime} \mathrm{S}, 008^{\circ} 20.0380^{\prime} \mathrm{E}, 3978 \mathrm{~m}$, 20.XII.2003, 1 o. - CP 22, stn R10, 0546.9700'S, $009^{\circ} 44.1828^{\prime} \mathrm{E}, 3121 \mathrm{~m}, 3 . \mathrm{I} .2004,1$ ․

\section{DESCRIPTION}

Colour of trunk of preserved specimens is reddishbrown. In one female only small proximal part of proboscis is attached to trunk, rest damaged. Trunk is cylindrical, $30 \mathrm{~mm}$ long and $12 \mathrm{~mm}$ across broadest part. Part of body wall damaged on ventral side of trunk. In other two specimens, probosces are missing and posterior ends of trunk are damaged. Anterior end of trunk covered with small rounded papillae, remainder of trunk smooth and devoid of papillae. Single genital pore is located about $5 \mathrm{~mm}$ away from anterior end of trunk (Fig. 1A). Ventral setae absent.

Gonoducts one pair (Fig. 1B), large, sac-like, uniting proximally beneath nerve cord and opening to exterior by single genital pore. In one female, gonoducts compactly filled with eggs. Gonostomes small, basal in position (Fig. 1B). Gonostomal lips with minute lobes around margin. Except for oesophagus and foregut, rest of alimentary canal is damaged in all specimens including blood system and anal vesicles.

\section{REMARKS}

Alomasoma belyaevi was originally described by Zenkevitch (1964) from the North-West Pacific Ocean at depths ranging from 2826-2843 m. Zenkevitch (1966) also reported the occurrence of this species in the Gulf of Panama. Alomasoma belyaevi has been recorded and briefly described by Saiz-Salinas et al. (2000) from Antarctic and adjacent waters. The latter authors have described male specimens in the genus Alomasoma for the first time. According to Stephen \& Edmonds (1972) all the specimens have been found at great depths.

The anatomy of this species is fairly well known as it has been described from numerous specimens.

Alomasoma belyaevi is close to $A$. rhynchollulus DattaGupta, 1981 from the North Atlantic. According to DattaGupta (1981), A. rhynchollulus differs from all the other species in the genus in possessing a minute triangular proboscis. The discovery of A. belyaevi from the East Equatorial Atlantic Ocean is a new record for this region which considerably extends its range of distribution. 

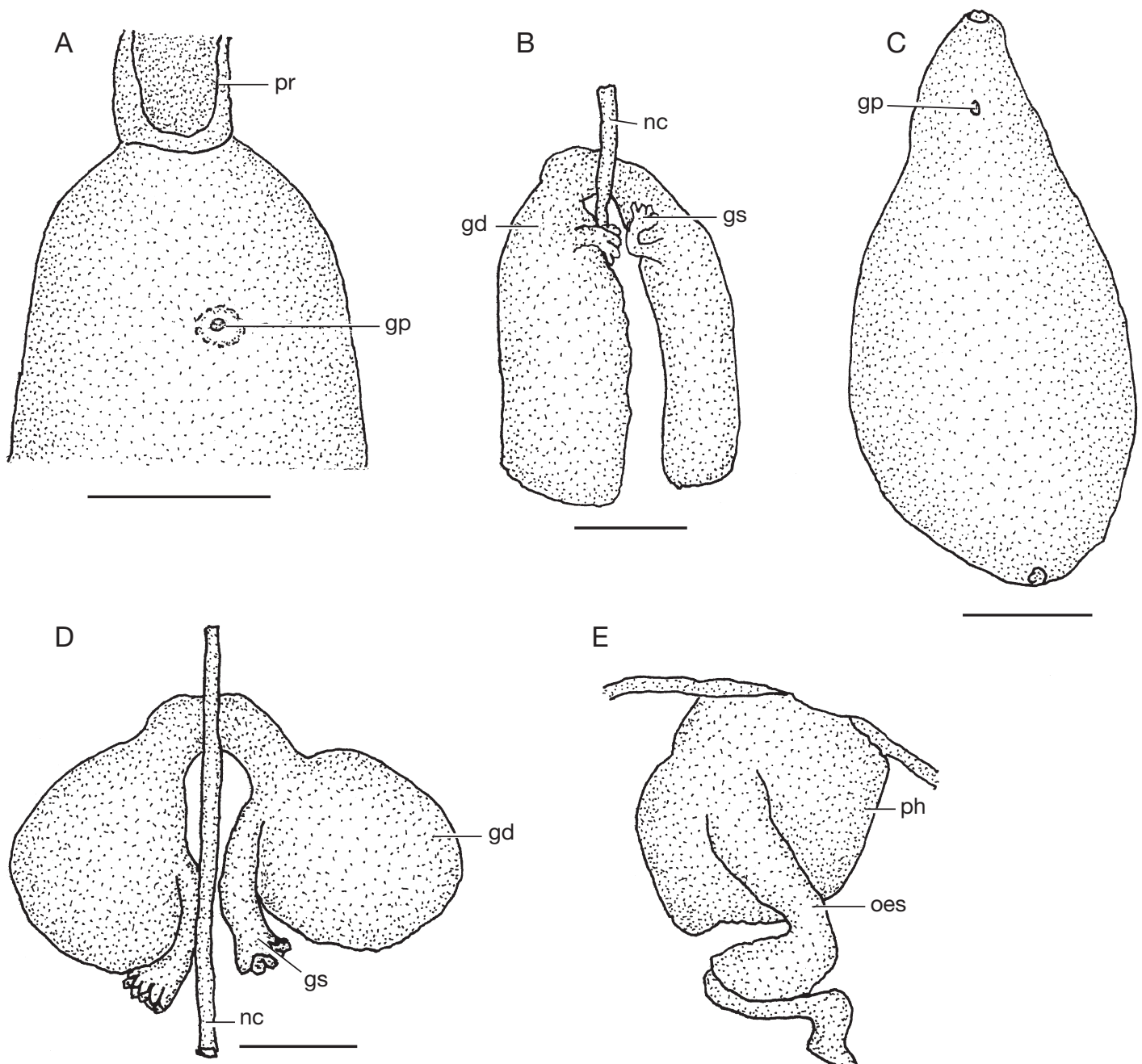

E

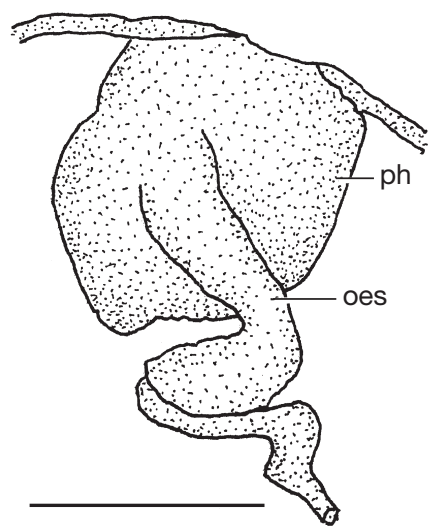

FIG. 1. - A, B, Alomasoma belyaevi Zenkevitch, 1964; A, ventral view of anterior part of female; B, gonoducts; C-E, A. nordpacificum Zenkevitch, 1958; C, ventral view of trunk of female; D, gonoducts; E, anterior end of trunk cavity showing the pharynx and oesophagus. Abbreviations: gd, gonoduct; gp, genital pore; gs, gonostome; nc, nerve cord; oes, oesophagus; ph, pharynx; pr, proboscis. Scale bars: A, $2 \mathrm{~mm}$; B, $1 \mathrm{~mm}$; C, E, $4 \mathrm{~mm}$; D, $0.5 \mathrm{~mm}$.

Alomasoma nordpacificum Zenkevitch, 1958 (Fig. 1C-E)

MATERIAL EXAMINED. - East Equatorial Atlantic Ocean. Gulf of Guinea, BIOZAIRE3, CP 13, stn ZB-C, 7039.7530'S, $10^{\circ} 1.2916$ 'E, $3991 \mathrm{~m}, 23 . \mathrm{XII} .2003,2$ 우요.

\section{DESCRIPTION}

Colour of trunk of preserved specimens is beige. Probosces missing in both specimens. Posterior end of trunk damaged in one female. In other specimen trunk is pear-shaped (Fig. 1C), $35 \mathrm{~mm}$ long and $17 \mathrm{~mm}$ across broadest part. Integument is thick and opaque in anterior half of trunk but thin and transparent in posterior half. Round to oval papillae closely arranged only on anterior half of trunk, posterior half is smooth and devoid of papillae. Single genital pore is located about $5 \mathrm{~mm}$ away from anterior end of trunk (Fig. 1C). Ventral setae absent. 
Gonoducts one pair (Fig. 1D), small, spherical, unite proximally beneath nerve cord and open to exterior by a single genital pore. Gonostomes set on long stalks, basal in position. Gonostomal lips petaloid (Fig. 1D). Only foregut is intact, rest of intestine is missing including blood system. Pharynx is bulbous, clearly demarcated from oesophagus (Fig. 1E). Gut contents moulded into oval faecal pellets. Anal vesicles are branching tubules terminating in ciliated funnels and opening into rectum.

\section{REMARKS}

The genus Alomasoma is distinguished in possessing two gonoducts which unite proximally to form a common duct which opens to the exterior by a single genital pore. The gonostomes are basal and set on long stalks. Anal vesicles are branching tubules terminating in ciliated funnels. The genus Alomasoma is closely related to the genus Amalosoma Fisher, 1948. In the latter genus the two gonoducts open to the exterior separately. Furthermore, a specialized genital slit is present anterior to the genital pore in Amalosoma but absent in Alomasoma.

The species $A$. nordpacificum has been described by DattaGupta (1981) and Biseswar (2005) from the North Atlantic. The discovery of this species in the East Equatorial Atlantic Ocean considerably extends its range of distribution.

Genus Choanostomellia Zenkevitch, 1964

Choanostomellia filatovae (Zenkevitch, 1964) (Fig. 2A, B)

Material eXAMineD. - East Equatorial Atlantic Ocean. Continental margin of Angola, ZAIANGO-BIOL 2, CP 07, 7³0.87'S, $11^{\circ} 33.95^{\prime} \mathrm{E}, 1359 \mathrm{~m}, 28$.VIII.2000, 1 ㅇ.

Gulf of Guinea, BIOZAIRE 3, CP 11, stn ZB-D, $5^{\circ} 50.5840^{\prime} \mathrm{S}, 8^{\circ} 20.0380$ 'E, $3978 \mathrm{~m}, 20 . X I I .2003$, 1 ․

\section{DESCRIPTION}

Colour of proboscis and trunk of preserved specimen from off coast of Angola is cream while in specimen from Gulf of Guinea proboscis is pink and trunk is reddish-brown. In former specimen proboscis is $120 \mathrm{~mm}$ long including collar which is $7 \mathrm{~mm}$ broad. Corresponding measurements of specimen from Gulf of Guinea is $45 \mathrm{~mm}$ and $12 \mathrm{~mm}$ respectively. Trunk of this specimen is $80 \mathrm{~mm}$ long and $18 \mathrm{~mm}$ across broadest part. Only $40 \mathrm{~mm}$ of anterior end of trunk of specimen from off coast of Angola is intact, rest is missing. Proboscis is broad proximally but narrows gradually towards distal end (Fig. 2A). Anterior margin of proboscis is evenly rounded. In proximal half lateral margins of proboscis curl inwards forming tubular structure. Broad funnel-like collar is incised ventrally (Fig. 2A). Body wall is thick and opaque. Elongated papillae are densely arranged in transverse rows on anterior half of trunk, posterior half is smooth and devoid of papillae. Single genital pore is located on raised eminence of body wall about $5 \mathrm{~mm}$ away from anterior tip of trunk (Fig. 2A).

Distal ends of gonoducts are damaged in both specimens. Single, tubular gonoduct is located on left side of nerve cord with basally placed gonostome (Fig. 2B). Gonostomal lip with small lobes around margin. Only foregut is intact, rest of alimentary canal is missing including blood system. Coelom is filled with oval faecal pellets. Anal vesicles are tubular into which open many branching tubules terminating in ciliated funnels (Fig. 2C).

\section{REMARKS}

The genus Choanostomellia is distinguished by the presence of a deeply incised, funnel-like collar that surrounds the proximal part of the proboscis and pharynx and a single gonoduct on the left side of the nerve cord with a basally located gonostome. The genus is also characterised by the absence of ventral setae. Three species are currently known in the genus Choanostomellia, namely, C. filatovae, C. bruuni Zenkevitch, 1964 and C. vinogradovae Murina, 1978. Choanostomellia bruuni was originally recorded from the northern Arabian Sea at a depth of $3676 \mathrm{~m}$ while C. filatovae was recorded off Japan in waters $1693 \mathrm{~m}$ deep (Stephen \&Edmonds 1972). DattaGupta (1981) recorded and redescribed both these species from the North Atlantic Ocean. The species C. vinogradovae was recorded by Murina (1978) from the western Pacific at a depth of $4395 \mathrm{~m}$. The present specimens from the East Equatorial Atlantic Ocean closely conform with 
the descriptions provided by Zenkevitch (1964) and DattaGupta (1981). Unfortunately, the description provided by Zenkevitch (1964) makes no mention of the anal vesicles. The anal vesicles were also missing in the specimen described by DattaGupta (1981). The anal vesicles of $C$. filatovae is described here for the first time. The specimen from off the coast of Angola with a proboscis length of $120 \mathrm{~mm}$ is much larger in size than those described previously.

The discovery of $C$. filatovae from off the coast of Angola in the vicinity of $7^{\circ} \mathrm{S}$ latitude is the first report of its occurrence in this region and considerably extends its range of distribution.

Genus Torbenwolffia Zenkevitch, 1966

Torbenwolffia galatheae Zenkevitch, 1966 (Fig. 2D-F)

Material eXamined. - East Equatorial Atlantic Ocean. Gulf of Guniea, BIOZAIRE 3, CP 11, stn ZB-D, $05^{\circ} 50.5840^{\prime} \mathrm{S}, 008^{\circ} 20.0380^{\prime} \mathrm{E}, 3978 \mathrm{~m}, 20 . X I I .2003$, 1 ㅇ.

\section{DESCRIPTION}

Colour of trunk of preserved specimen is reddishbrown, proboscis missing. Trunk cylindrical, $46 \mathrm{~mm}$ long and $15 \mathrm{~mm}$ across broadest part. Posterior half of trunk damaged on dorsal side. Rounded papillae densely distributed over entire surface of trunk, aligned roughly in transverse rows, slightly larger in middle region of trunk. Integument is thick and opaque. Single genital pore is located about $5 \mathrm{~mm}$ away from anterior end of trunk (Fig. 2D). Ventral setae absent.

Single tubular gonoduct is located on left side of nerve cord (Fig. 2E). Proximal end of gonoduct passes under nerve cord to open in median line. Gonostome basal in position. Gonostomal lip is smooth (Fig. 2E). Anal vesicles consist of two saclike structures covered with tubules terminating in ciliated funnels (Fig. 2F). Anal vesicles open into prominent cloacal bulb.

\section{REMARKS}

Distinguishing features of the genus Torbenwolffia include a proboscis with bilobed anterior extrem- ity; no ventral setae; single gonoduct and short unbranched anal vesicles. Torbenwolffia galatheae was described originally by Zenkevitch (1966) based on specimens collected from the Kermadec Trench in the Pacific Ocean. All the specimens were found at great depths. The present specimen closely approaches the description given by Zenkevitch (1966). One minor difference, however, lies in the structure of the anal vesicles, which in the present specimen are two sac-like structures into which open many excretory tubules terminating in ciliated funnels.

In the original description of the species Zenkevitch (1966) has mentioned that the gonoduct is located on the right side. This is incorrect as his illustration clearly shows that this organ is located on the left side of the animal.

Torbenwolffia galatheae was recorded and described by Biseswar (2005). The specimens were collected in the Porcupine Abyssal Plain in the North-East Atlantic at a depth of $4847 \mathrm{~m}$. The discovery of the species in the East Equatorial Atlantic Ocean is a new record for this region and extends its range of distribution.

\section{Genus Sluiterina Monro, 1927}

Sluiterina flabellorhynchum Murina, 1976

(Fig. 3A-D)

MAterial eXAMINED. - East Equatorial Atlantic Ocean. West African equatorial margin, BIOZAIRE 2, KGS 43, stn R, 0547.975'S, 0942.422’E, 3164 m, 28.XI.2001, 1 오.

Gulf of Guinea, BIOZAIRE3, CP 17, stn R3, 0548.6960'S, 0943.9829'E, 3156 m, 30.XII.2003, 2 우우 - CP 11, stn ZB-D, $05^{\circ} 50.5840^{\prime} \mathrm{S}, 008^{\circ} 20.0380^{\prime} \mathrm{E}, 3978 \mathrm{~m}$, 20.XII.2003, 1 우. - CP 21, stn R9, 0547.4990'S, $009^{\circ} 43.8038^{\prime} \mathrm{E}, 3130 \mathrm{~m}$, 3.I.2004, 1 ㅇ. - CP 18, stn R4, 0548.1530'S, 00943.9136'E, 3142 m, 30.XII.2003, 1 오.

\section{DESCRIPTION}

Colour of proboscis is pink, trunk is reddish-brown in preserved state. Proboscis is truncate, $19-115 \mathrm{~mm}$ long with two small lobes at distal end (Fig. 3A). Lateral margins of proboscis curl inwards and unite at base forming cup around mouth. Trunk 

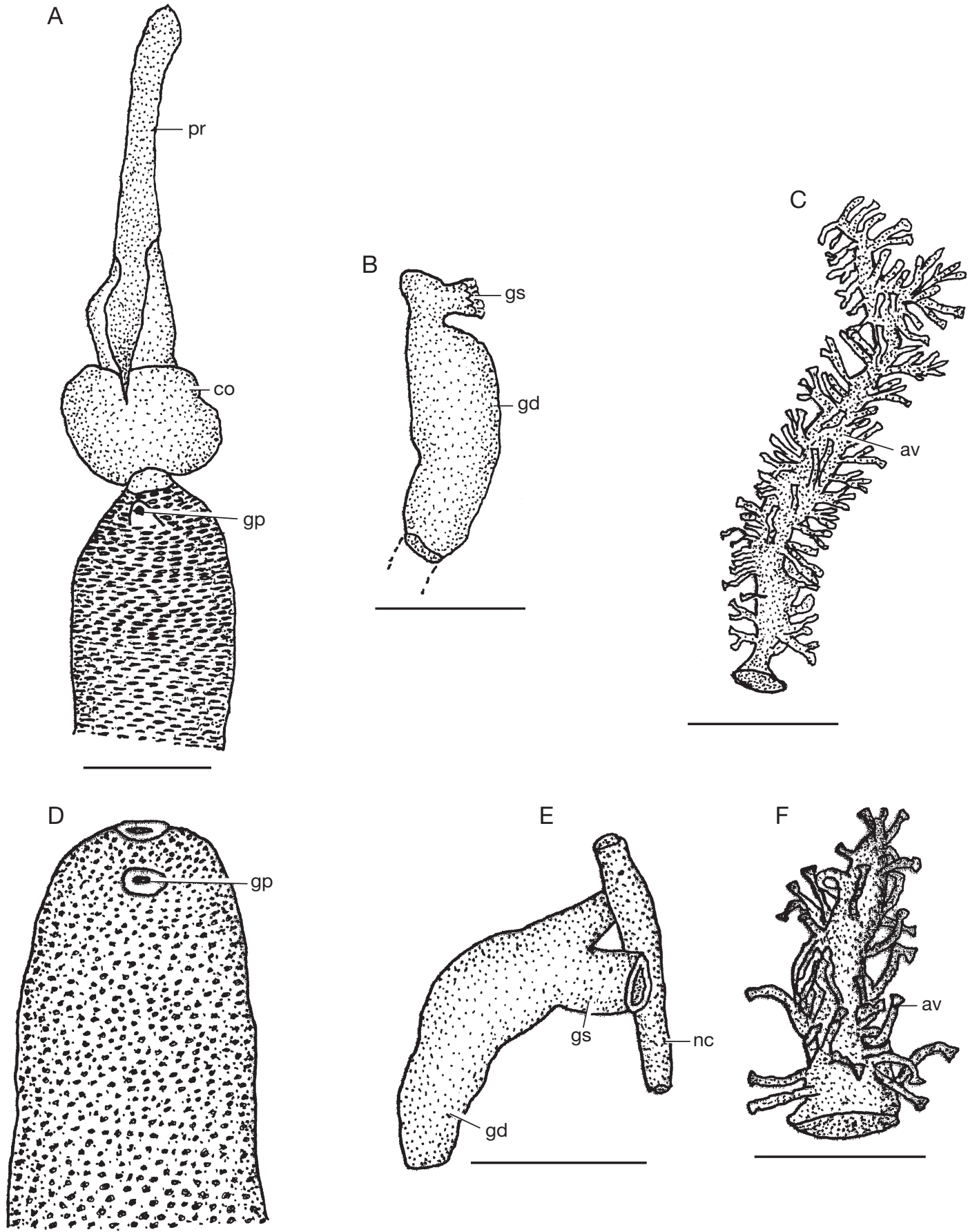

FIG. 2. - A-C, Choanostomellia filatovae (Zenkevitch, 1964); A, ventral view of anterior part of female; B, gonoduct; C, right anal vesicle; D-F, Torbenwolffia galatheae Zenkevitch, 1966; D, ventral view of anterior part of female; E, gonoduct; F, left anal vesicle. Abbreviations: av, anal vesicle; co, collar; gd, gonoduct; gp, genital pore; gs, gonostome; nc, nerve cord; pr, proboscis. Scale bars: A, $5 \mathrm{~mm}$; B, $2 \mathrm{~mm}$; C, E, F, $1 \mathrm{~mm}$; D, $4 \mathrm{~mm}$. 
is cylindrical, $32-77 \mathrm{~mm}$ in length and $11-17 \mathrm{~mm}$ across broadest part. Integument is thick and opaque. Papillae minute, arranged in rings on anterior half of trunk; in posterior half integument is smooth. Genital pore is conspicuous about $6 \mathrm{~mm}$ away from anterior tip of trunk (Fig. 3A). Ventral setae absent. Anus located on small, conical projection.

Single, tubular gonoduct is located on left side of nerve cord (Fig. 3B). gonostome funnel-shaped, opening in middle of gonoduct. Gonostomal lips petaloid. Gut contents moulded into oval faecal pellets. Prominent dorsal vessel arises from wall of intestine, passes anteriorly dorsal to pharynx and enters proboscis (Fig. 3C). Neurointestinal vessel is single throughout. Anal vesicles are two slender sacs, $20 \mathrm{~mm}$ in length bearing densely aggregated tubules terminating in ciliated funnels (Fig. 3D).

\section{REMARKS}

The genus Sluiterina is distinguished by the presence of a truncate proboscis. Lateral margins of the proboscis fuse at the base to form a shallow cup around the mouth. The single gonoduct has a gonostome that may be basal or central in position. Ventral setae are absent.

Five species are currently assigned to the genus, namely, S. sibogae (Sluiter, 1902), S. vitjazi Murina, 1976, S. flabellorhynchum, S. alba Murina, 1978 and S. kaikourae Edmonds, 1985. The original description of the species $S$. flabellorhynchum is based on specimens from the Scotia Sea (South Atlantic). This species was recorded and described from the Antarctic by Saiz-Salinas et al. (2000). The specimens on hand closely approach the description given by Murina (1976). Sluiterina flabellorhynchum differs from all the other species in the genus in possessing a gonostome that opens in the middle of the gonoduct. The discovery of this species in the South-East Atlantic is a new record for the region and considerably extends its range of distribution.

\section{Sluiterina sibogae (Sluiter, 1902)}

(Fig. 3E, F)

Material eXamined. - East Equatorial Atlantic Ocean. Gulf of Guinea, BIOZAIRE 3, CP 10, stn
ZB-D, 550.6300'S, 8²0.0600'E, 3977 m, 19.XII.2003, 2 우우 - CP 17, stn R3, 548.6960'S, 943.9829'E, 3156 m, 30.XII.2003, 5 우. - CP 11, stn ZB-D, 5'50.5840'S, 8²0.0380'E, 3978 m, 20.XII.2003, 3 ㅇ․ - CP 12, stn ZB-D, $5^{\circ} 50.2300^{\prime} S, 8^{\circ} 20.2385^{\prime} \mathrm{E}$, 3975 m, 20.XII.2003, 9 ㅇ. - CP 24, stn ZB-R, $5^{\circ} 55.143$ 'S, $009^{\circ} 41.6068^{\prime} \mathrm{E}, 3230 \mathrm{~m}$, 4.I.2004, 10 우.CP 21, stn R9, 0547.4990'S, 00943.8038'E, $3130 \mathrm{~m}$, 3.I.2004, 5 우우 - CP 23, stn R11, 0545.9180'S, $009^{\circ} 43.9860$ 'E, $3147 \mathrm{~m}$, 3.I.2004, 3 우. - CP 18, stn R4, 0548.1530'S, 00943.9136'E, 3142 m, 30.XII.2004, 7 우오.

\section{DESCRIPTION}

Colour of proboscis and trunk of preserved specimens is reddish-brown. Proboscis is truncate, $19-41 \mathrm{~mm}$ long, anterior half is flat and tapers distally (Fig. 3E). At proximal end, lateral margins of proboscis curl inwards and unite forming funnel around mouth (Fig. 3E). Trunk is cylindrical, 51-97 $\mathrm{mm}$ in length and $10-17 \mathrm{~mm}$ across broadest part. Integument is thick and opaque at extremities of trunk but much thinner in middle region. In some specimens anterior end of trunk has transverse wrinkles. Papillae round to oval, densely arranged at anterior and posterior ends of trunk, aligned roughly in transverse rows. Ventral setae absent. Single genital pore is located at tip of conical eminence of body wall a few millimetres away from anterior end of trunk (Fig. 3E).

Gonoduct single, sac-like or tubular, located on left side of nerve cord, with round eggs in sexually mature specimens (Fig. 3F). Gonostome basal in position, gonostomal lip with minute lobes around margin (Fig. 3F). Gut contents moulded into oval faecal pellets. Blood system also damaged due to poor preservation. Anal vesicles are two elongated tubular sacs covered with branched tubules terminating in ciliated funnels.

\section{REMARKS}

The species Sluiterina sibogae was originally described from a single female from Indonesia collected at a depth of $4391 \mathrm{~m}$. The present specimens from the East Equatorial Atlantic Ocean closely approach the descriptions given by Sluiter (1902). Similarities are evident in the structure of the proboscis, the position of the gonostome and the distribution of the dermal papillae. The anal vesicles have not been described 

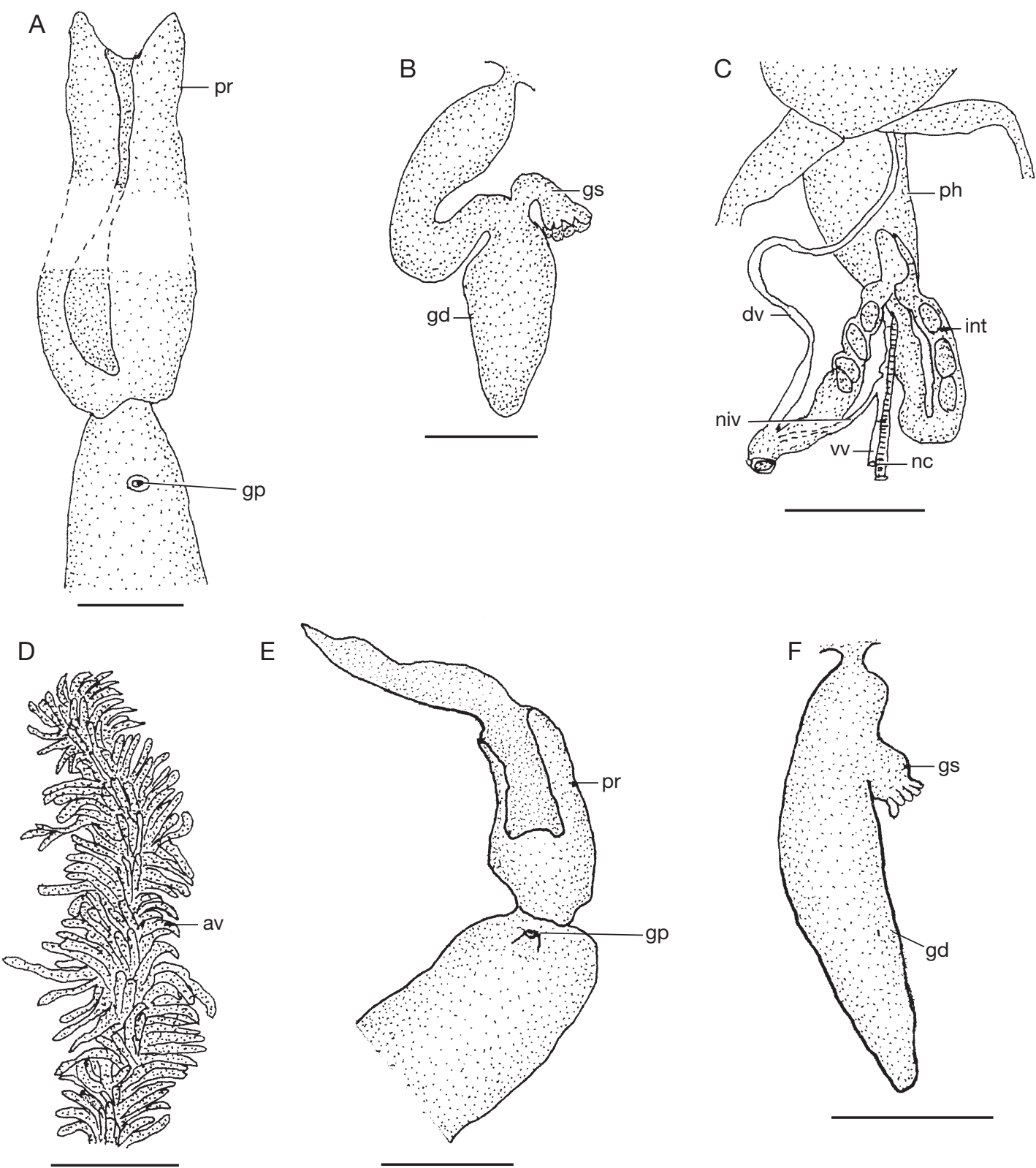

FIG. 3. - A-D, Sluiterina flabellorhynchum Murina, 1976; A, ventral view of anterior part of female; B, gonoduct; C, anterior end of trunk cavity showing the blood system; D, anal vesicles; E, F, Sluiterina sibogae (Sluiter, 1902); E, ventral view of anterior part of female; F, gonoduct. Abbreviations: av, anal vesicle; dv, dorsal vessel; gd, gonoduct; gp, genital pore; gs; gonostome; int, intestine; nc, nerve cord; niv, neurointestinal vessel; ph, pharynx; pr, proboscis; vv, ventral vessel. Scale bars: A, C, 4 mm; B, F, 2 mm; D, 1 mm; E, 5 mm.

by Sluiter (1902). In the present specimens the anal vesicles are two sac-like structures bearing branched tubules terminating in ciliated funnels. Sluiterina sibogae was redescribed by Biseswar (2005). The specimen was collected in the Porcupine Abyssal Plain in the North-East 
Atlantic at a depth of $4839 \mathrm{~m}$. The discovery of this species in the East Equatorial Atlantic Ocean is a new record and which considerably extends its range of distribution.

\section{?Sluiterina sp.}

(Fig. 4A, B)

Material examined. - East Equatorial Atlantic Ocean. Gulf of Guinea, BIOZAIRE 3, CP 21, stn R9, 0547.4990’S, 00943.8038’E, 3130 m, 3.I.2004, 1 ㅇ.

\section{DESCRIPTION}

Colour of trunk is reddish-brown. Only small, basal stump of proboscis is attached to trunk, rest is missing. Posterior end of trunk is missing, only $40 \mathrm{~mm}$ of anterior end is intact. Trunk is cylindrical, $9 \mathrm{~mm}$ across broadest part. Integument is thick and opaque. Papillae microscopic, round, aligned in transverse rows. Genital pore is transverse slit located $4 \mathrm{~mm}$ away from anterior tip of trunk (Fig. 4A). Ventral setae absent.

Internally, only foregut and small portion of midgut is intact, rest of alimentary canal is missing including blood vascular system. Contents of gut moulded into oval faecal pellets. Single gonoduct, located on left side of nerve cord, consists of two parts (Fig. 4B). Tube leading from distal, spherical accessory sac opens into middle of saclike, thick-walled gonoduct (Fig. 4B). Proximal end of gonoduct passes under nerve cord to open in median line. Stalked, funnel-shaped gonostome also opens in middle of gonoduct close to opening of accessory sac (Fig. 4B). Gonostomal lips with small lobes around margin. Elongate ovary located on right side of nerve cord adjacent to gonoduct (Fig. 4B). Anal vesicles not seen.

\section{REMARKS}

The present specimen from the East Equatorial Atlantic Ocean has been tentatively assigned to the genus Sluiterina on account of the presence of a single gonoduct and the absence of ventral setae. Unfortunately the specimen is incomplete. Except for the gonoduct which is intact and well preserved, the rest of the internal organs are missing. The structure of the gonoduct, with an accessory sac opening into it, is rather unusual. To date, such a gonoduct has not been observed in any other bonelliid species. The taxonomic status of this specimen is uncertain and will have to await a detailed examination of additional material from that region. It is very likely that additional specimens may reveal that he specimen on hand belongs to a new genus.

\section{Genus Bonellia Ronaldo, 1821}

Bonellia pumicea Sluiter, 1891

(Fig. 4C)

Material eXAmined. - East Equatorial Atlantic Ocean. BIOZAIRE 1, ROV-PL 79-3 CL 3, stn ZB-B, 07²18.31'S, 0120․83'E, 374 m, 7.I.2001, 1 ․

\section{DESCRIPTION}

Colour of trunk in preserved specimen is grey; proboscis is missing. Trunk is oval in outline, $1.5 \mathrm{~mm}$ long and $1 \mathrm{~mm}$ across broadest part (Fig. 4C). Integument is thin and transparent, coils of gut visible. Single ventral seta present on left side, right one is missing, probably fallen off. Seta goldenyellow with cylindrical shaft and flattened, curved terminal blade. Papillae microscopic, visible only at anterior end of trunk.

Gonoduct single, on left side of nerve cord with basally located gonostome, gut contents moulded into oval faecal pellets, anal vesicles two main tubes bearing tubules which branch once or twice before terminating in ciliated funnels.

\section{REMARKS}

The species $B$. pumicea was originally described from a single female from Sumatra by Sluiter (1891). This species is fairly well known as it has been recorded and redescribed from the North Atlantic by DattaGupta (1981) and Biseswar (1992). Bonellia pumicea is closely related to B. plumosa DattaGupta, 1981 but differs in the structure of the body wall and blood vascular system. Stephen \& Edmonds (1972) have mentioned the presence of white papillae as the main feature to separate $B$. pumicea from the rest of the species in the genus Bonellia. According 

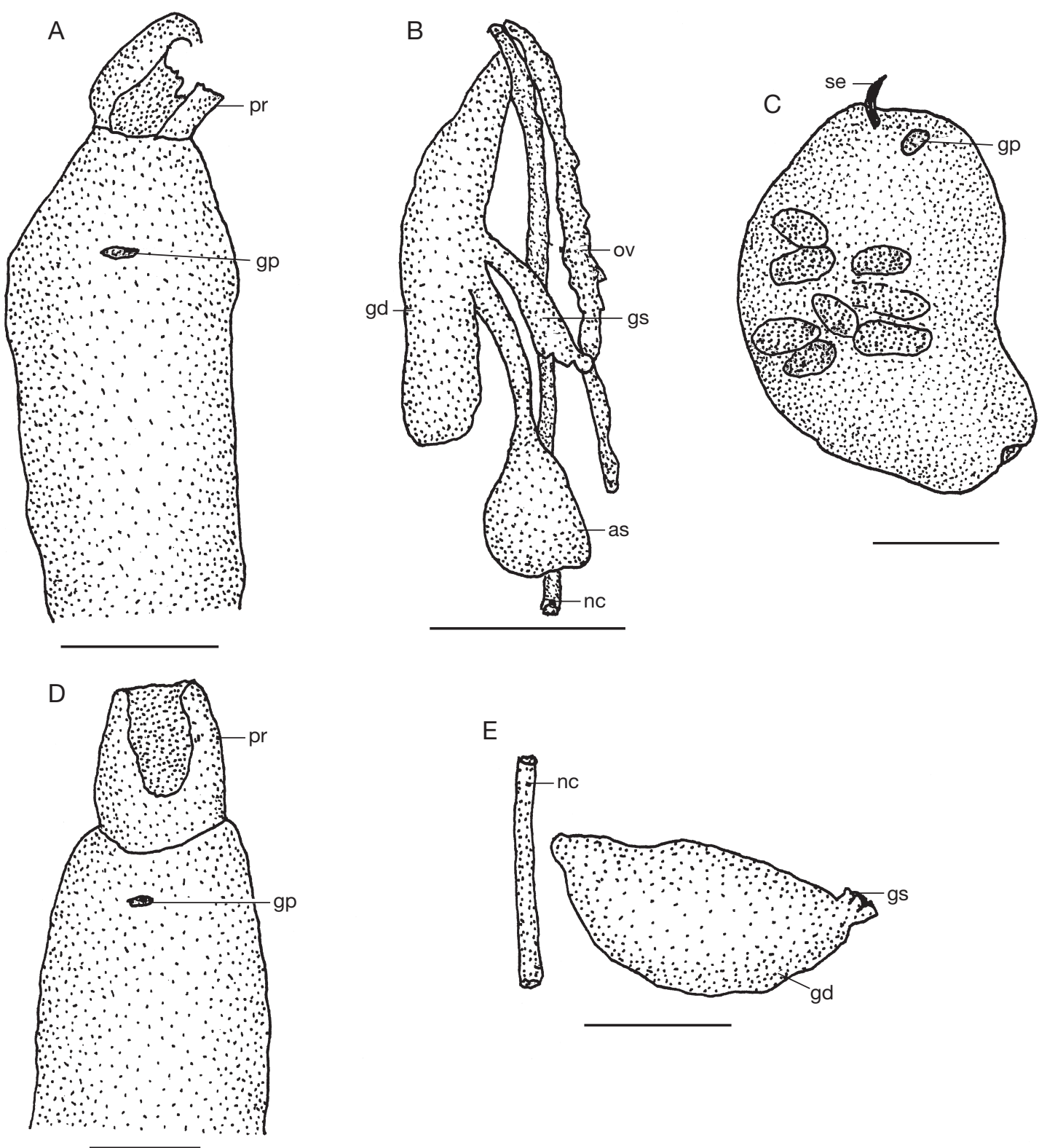

FIG. 4. - A, B, ?Sluiterina sp.; A, ventral view of anterior part of female; B, gonoduct; C, Bonellia pumicea Sluiter, 1891, ventral view of female; D, E, Eubonellia longistomum Fisher, 1946; D, ventral view of anterior part of female; E, gonoduct. Abbreviations: as, accessory sac; gd, gonoduct; gp, genital pore; gs, gonostome; nc, nerve cord; ov, ovary; pr, proboscis, se, seta. Scale bars: A, B, $3 \mathrm{~mm}$; C, E, $0.5 \mathrm{~mm}$; D, $1 \mathrm{~mm}$.

to DattaGupta (1981), B. plumosa has a broad ring sinus located at the junction of the pro- and mid-intestine.
The discovery of this species from the West African continental margin is a new record and extends its range of distribution southwards in the Atlantic. 
Genus Eubonellia Fisher, 1946

Eubonellia longistomum DattaGupta, 1981

(Fig. 4D, E)

Material examined. - East Equatorial Atlantic Ocean. Gulf of Guinea, BIOZAIRE 3, CP 11, stn ZB-D, $05^{\circ} 50.5840$ 'S, $008^{\circ} 20.0380^{\prime} \mathrm{E}, 3978 \mathrm{~m}, 20 . X I I .2003$, 1 ㅇ.

\section{DESCRIPTION}

Colour of proboscis of preserved specimen is cream, trunk is light pink. Only basal stump of proboscis is attached to trunk, rest is missing. Lateral margins of proboscis curl inwards and unite at proximal end forming narrow lower lip ventral to mouth (Fig. 4D). Only about $25 \mathrm{~mm}$ of anterior end of trunk is intact, posterior part missing. Trunk is cylindrical, $10 \mathrm{~mm}$ across broadest part. Integument is smooth and devoid of papillae, single genital pore is located a few millimetres away from anterior tip of trunk (Fig. 4D). Ventral setae absent.

Except for foregut, nerve cord and gonoduct, rest of internal organs missing. Single, sac-like gonoduct is located on right side of nerve cord (Fig. 4E). Gonostome distal in position, gonostomal lip with small lobes around margin (Fig. 4E).

\section{REMARKS}

Distinguishing features of the genus Eubonellia include a well-developed bifurcate proboscis; absence of ventral setae; single gonoduct on right side of nerve cord with terminal gonostome; anal vesicles are tubular.

The species E. longistomum is described originally by DattaGupta (1981) based on specimens in which the distal ends of the probosces were missing. This species was later recorded and redescribed by Biseswar (2005) from specimens collected from the Porcupine Abyssal Plain in the North-East Atlantic. The present specimen from the east Equatorial Atlantic is incomplete. However, it conforms with the description given by DattaGupta (1981) in all essential respects except for minor differences in the structure of the proboscis. The discovery of E. longistomum in the East Equatorial Atlantic is a new record for this region and extends its range of distribution.
Genus Protobonellia Ikeda, 1908

Protobonellia mitsukurii Ikeda, 1908

(Fig. 5A, B)

Material examined. - East Equatorial Atlantic Ocean. BIOZAIRE 2, KGS 39, stn D, 05 $50.985^{\prime}$ S, $008^{\circ} 21.805^{\prime} \mathrm{E}, 3950 \mathrm{~m}, 25 . \mathrm{XI} .2001,1$ ㅇ.

\section{DESCRIPTION}

Proboscis is cream, trunk is beige in preserved specimen. Proboscis is $4.5 \mathrm{~mm}$ long, broad, truncate with a constriction at distal end (Fig. 5A). Lateral margins of proboscis unite at base forming narrow lower lip ventral to mouth. Trunk is ovoid (Fig. 5A), $3.5 \mathrm{~mm}$ long and $2.6 \mathrm{~mm}$ across broadest part, damaged at posterior end. Integument is thick and opaque. Elongated papillae are transversely aligned over entire surface of trunk more prominent and densely aggregated at anterior end. Ventral setae golden-yellow, $3 \mathrm{~mm}$ in length with straight cylindrical shaft and flattened, curved terminal blade, terminating in a pointed tip (Fig. 5B).

Only small, proximal fragment of gonoduct is present on left side of nerve cord. Gonostome not seen, probably damaged due to poor preservation Anal vesicles missing.

\section{REMARKS}

The genus Protobonellia is distinguished by the presence of a truncated proboscis, a pair of ventral setae and a single gonoduct with a basally located gonostome. The species $P$. mitsukurii was originally described by Ikeda (1908) from a single specimen from Sagami Bay, Japan. This species was later recorded and redescribed by DattaGupta (1975, 1981). Except for some minor differences, the present specimen approaches the descriptions given by the above authors. Unfortunately, the anal vesicles and other internal organs are damaged in the specimen on hand. According to Ikeda (1908), the anal vesicles are two slender tubes that bear numerous long-stalked funnels.

Protobonellia mitsukurii has been recorded in the North Atlantic by DattaGupta (1981). Its discovery in the east Equatorial Atlantic Ocean is a new 
record for this region which extends its range of distribution.

\section{Protobonellia sp.}

(Fig. 5C)

Material EXAMINED. - East Equatorial Atlantic Ocean. West African continental margin, ZAIANGO-BIOL 2, KGS $16,07^{\circ} 28.75^{\prime} \mathrm{S}, 11^{\circ} 32.43^{\circ} \mathrm{E}, 1362 \mathrm{~m}$, 28.VIII.2000, 1 ㅇ.

\section{DESCRIPTION}

Colour of proboscis and trunk of preserved specimen is cream. Specimen is extremely small, total length including proboscis is $8 \mathrm{~mm}$. Proboscis is truncate, $3 \mathrm{~mm}$ in length; lateral margins curl inwards and unite at base forming narrow lower lips ventral to mouth (Fig. 5C). Trunk is oval (Fig. 5C), $5 \mathrm{~mm}$ long and about $2.5 \mathrm{~mm}$ across broadest part. Integument is thick and opaque. Anterior end of trunk covered with small, elongated papillae aligned roughly in transverse rows, remainder of integument is smooth. Genital pore not visible externally. Single ventral setae found in same vial is from the left side of animal as only basal cylindrical part of right seta was present in setal sac of specimen. Setae golden-yellow, consisting of cylindrical shaft with slightly curved terminal end tapering towards tip.

Single, minute, tubular gonoduct located on left side of nerve cord with basally located gonostome. Rest of internal organs missing probably damaged due to poor preservation.

\section{REMARKS}

Distinguishing features of the genus Protobonellia include the presence of a truncate proboscis, two ventral setae, a single gonoduct (left) with a basally located gonostome and anal vesicles that are elongate and dendritic.

Five species are currently known in the genus Protobonellia. The specimen on hand resembles P. mitsukurii in the structure of the proboscis but differs in lacking an interbasal muscle.

As the present specimen is extremely small with most of the internal organs missing, its taxonomic position is uncertain and will have to await the collection of additional material from that region.
Genus Pseudobonellia Johnston \& Tiegs, 1919

Pseudobonellia sp.

(Fig. 5D, E)

Material EXAMINED. - East Equatorial Atlantic Ocean. West African continental margin, ZAIANGO-BIOL 2, CP 09, $07^{\circ} 17.67^{\prime} \mathrm{S}, 12^{\circ} 4.67^{\circ} \mathrm{E}, 360 \mathrm{~m}, 29$.VIII.2000, 1 ㅇ․

\section{DESCRIPTION}

Colour of trunk white in preserved specimen. Trunk sac-like, $75 \mathrm{~mm}$ long and $20 \mathrm{~mm}$ across broadest part. Integument thin and transparent. Anterior $11 \mathrm{~mm}$ of trunk covered with raised papillae arranged in concentric rings. Round transparent papillae sparsely distributed over rest of trunk. Single seta on right side, minute, golden-brown in colour, with curved terminal blade terminating in pointed tip (Fig. 5D). Left seta is missing, probably fallen off. Interbasal muscle is absent.

Internally, only small part of foregut is present, rest of alimentary system is missing. Coelom filled with oval, pellet-like faeces. Gonoducts one pair, sac-like, located posterior to ventral setae, distal ends damaged (Fig. 5E). Gonostome not seen, probably damaged due to poor preservation. Male tube, small, located between proximal ends of gonoducts. Neurointestinal vessel is single throughout, opening into ventral vessel anterior to gonoducts (Fig. 5E). Anal vesicles not seen, probably damaged.

\section{REMARKS}

The genus Pseudobonellia is distinguished in possessing a bifid proboscis; trunk with two ventral setae; two gonoducts with distally located gonostomes and branched anal vesicles. Male carried in a small blind tube that projects into the coelom between the genital pores.

The genus Pseudobonellia contains a single species P. biuterina described originally by Johnston \& Tiegs (1919) from specimens collected from the Great Barrier Reef. Edmonds (1960, 1987) recorded and redescribed this species from specimens collected from Queensland and Western Australia. The present specimen has been assigned to the genus Pseudobonellia on account of the presence of two ventral setae, two gonoducts and a thin and transparent 
integument. Another feature in the present specimen is the presence of a male tube. This is the first record of the occurrence of this genus in the South-East Atlantic.

Genus Zenkevitchiola Murina, 1978

Zenkevitchiola sp.

(Fig. 5F)

Material eXAmined. - East Equatorial Atlantic Ocean. BIOZAIRE 1, KGS 27, stn ZB-D, 0549.937'S, $008^{\circ} 21.57^{\prime} \mathrm{E}, 4000 \mathrm{~m}, 10 . \mathrm{I} .2001,1$ 우.

\section{DESCRIPTION}

Colour of proboscis is cream, trunk is beige in preservative. Proboscis is truncate $0.5 \mathrm{~mm}$ long with lateral margins curled ventrally forming a groove leading to mouth; distal extremity is curved and widened (Fig. 5F). Trunk is pear-shaped (Fig. 5F) $0.7 \mathrm{~mm}$ in length and $0.4 \mathrm{~mm}$ across broadest part. Integument is thin and transparent. Papillae minute, round, visible at anterior end of trunk, rest of integument is smooth. Ventral setae absent. Internal organs not seen, probably damaged due to poor preservation.

\section{REMARKS}

The specimen on hand has been tentatively assigned to the genus Zenkevitchiola Murina, 1978 on account of the absence of ventral setae, the thin and transparent integument and the structure of the proboscis. As the specimen is minute it is very likely that it is still a juvenile. The proboscis of the present specimen resembles that of $Z$. brevirostris Murina, 1978, described from a single female collected near southern Tasmania (Murina 1978). According to Murina (1978) and Edmonds (1987), the distal extremity of the proboscis is curved and widened. The monotypic genus Zenkevitchiola is characterised by the presence of a single gonoduct located on the right side of the nerve cord, a basally located gonostome and tubular anal vesicles that taper distally.

A closer study of additional material in the future will help resolve its taxonomic position. The species
$Z$. brevirostris has been recorded and redescribed from the North-East Atlantic by Biseswar (2006). Its discovery in the East Equatorial Atlantic Ocean is a new record for the region and extends its range of distribution considerably.

\section{Genus Bruunellia Zenkevitch, 1966}

\section{Bruunellia sp.}

(Fig. 5G, H)

Material examined. - East Equatorial Atlantic Ocean. Gulf of Guinea, BIOZAIRE 3, MTB 30, stn R9, $05^{\circ} 47.5100^{\prime} \mathrm{S}, 009^{\circ} 42.6576$ 'E, $3154 \mathrm{~m}, 1 . \mathrm{I} .2004,1$ 우.

\section{DESCRIPTION}

Colour of trunk of preserved specimen is pink. Proboscis and anterior end of trunk missing. Trunk cylindrical, $11 \mathrm{~mm}$ across broadest part. Integument thick and opaque. Papillae elongate, microscopic, discernible only at anterior end of trunk, rest of integument is smooth. Anal rosette surrounds anal aperture (Fig. 5G). Body wall at posterior tip of trunk with concentric series of ridges. Opening of single anal vesicle located on conspicuous, conical eminence of body wall (Fig. 5G).

Except for rectum and anal vesicle rest of internal organs missing. Single, crumpled, flower-like anal vesicle located on right side of rectum (Fig. $5 \mathrm{H}$ ). Flaps of anal vesicle covered with irregularly arranged tubules terminating in ciliated funnels. Short duct leading from anal vesicle passes through body wall and opens to exterior on conical muscular projection at posterior tip of trunk (Fig. 5G).

\section{REMARKS}

The present specimen has been assigned to the genus Bruunellia on account of the presence of an anal rosette. The only species in the genus Bruunellia is B. bandae Zenkevitch, 1966. The specimens were collected from the Banda Trench at a depth of $7250 \mathrm{~m}$. The anatomy of this species is not well known and needs further investigation. There is no information on the gonoducts, anal vesicles and the alimentary and blood vascular system. 


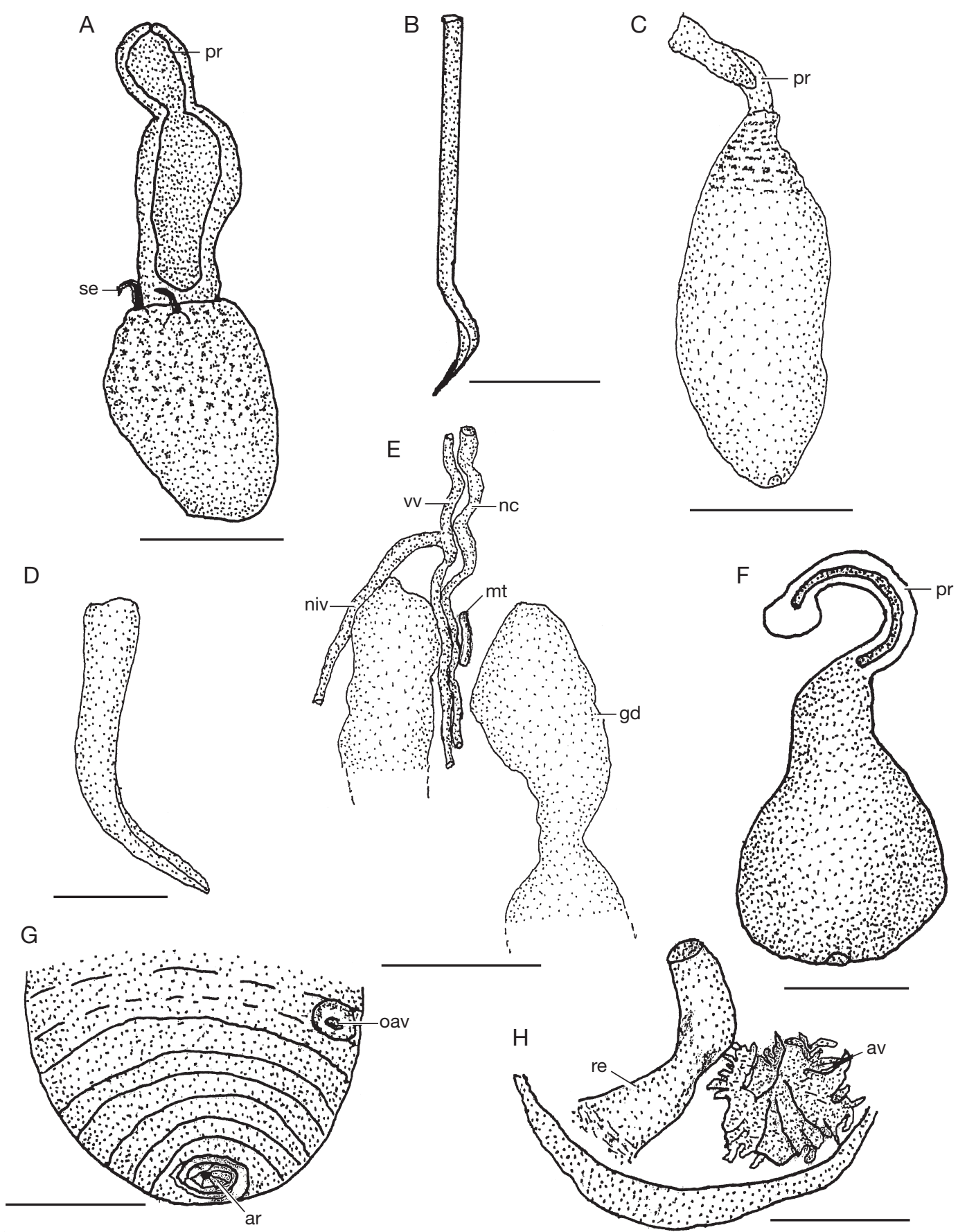

FIG. 5. - A, B, Protobonellia mitsukurii Ikeda, 1908; A, ventral view of female; B, ventral seta; C, Protobonellia sp., ventral view of female; D, E, Pseudobonellia sp.; D, ventral seta; E, gonoducts; F, Zenkevitchiola sp., ventral view of female; G, H, Bruunellia sp.; $\mathbf{G}$, posterior end of trunk of female showing anal rosette; $\mathbf{H}$, posterior end of trunk cavity showing rectum and anal vesicle. Abbreviations: ar, anal rosette; av, anal vesicle; gd, gonoduct; $\mathbf{m t}$, male tube; nc, nerve cord; niv, neurointestinal vessel; oav, opening of anal vesicle; pr, proboscis; re, rectum; se, seta; vv, ventral vessel. Scale bars: A, H, 2 mm; B, E, 1 mm; C, D, F, 0.25 mm; G, 5 mm. 
The structure of the anal vesicle in the specimen on hand is rather unusual. Such an anal vesicle has not been described in any other echiuran species so far. Detailed studies on additional material in the future will shed more light on the anatomy of this species and help resolve its taxonomic position.

\section{Acknowledgements}

The ZAIANGO-BIOL 2 and the BIOZAIRE cruises that were undertaken between August 2000 and January 2004 were part of a general study programme on the West African continental margin in the framework of scientific and technical cooperation between Total-Fina-Elf and Ifremer. Grateful acknowledgements are due to the following: the biological team under Myriam Sibuet, chief scientist of the ZAIANGO-BIOL 2 and BIOZAIRE 1 and 2 cruises; the biological team under Alexis Khripounoff, chief scientist of the BIOZAIRE 3 cruise, Joëlle Galeron of the CENTOB, Ifremer, Centre de Brest, France for the loan of the echiuran specimens of this report and the University of Kwa-Zulu-Natal for providing laboratory facilities. Thanks are also due to Professor A. S. Thandar for helpful suggestions during the preparation of this report and $\mathrm{Mr} \mathrm{G}$. Ganesan for technical assistance.

\section{REFERENCES}

BISESWAR R. 1992. - Some deep-sea echiurans of the North-East Atlantic. Bulletin du Muséum national d'Histoire naturelle Paris, 4e série, sect. A, 14 (3-4): 639-654.

BISESWAR R. 2005. - Report on some deep-sea echiurans (Echuira) of the North-East Atlantic. Zoosystema 27 (1): 37-46.

BISESWAR R. 2006. - Additions to the deep-sea echiuran (Echiura) fauna of the North-East Atlantic. Zoosystema 28 (4): 853-864.

DATTAGUPTA A. K. 1975. - Taxonomic notes on two echiurans (Echuira) of the Vema Collections. Proceedings of the Zoological Society of Calcutta 28: 19-22.

Dattagupta A. K. 1981. - Atlantic echiurans. Part 1. Report on twenty-two species of deep-sea echiurans of the North and the South Atlantic Oceans. Bulletin du Muséum national d'Histoire naturelle Paris, $4 \mathrm{e}$ série, sect. A, 3 (2): 353-378.

EDMONDS S. J. 1960. — Some Australian Echiuroids (Echiuroidea). Transactions of the Royal Society of South Australia 83: 89-96.

EDMONDS S. J. 1987. - Echiurans from Australia (Echiura). Records of the South Australian Museum 32 (2): 119-138.

IKEDA I. 1908. - Note on a new deep-sea echiuroid Protobonellia mitsukurii nov. gen. et sp. Annotationes Zoologicae Japonenses 6: 250-265.

Johnston T. H. \& Tiegs O. W. 1919. - Pseudobonellia, a new echiuroid from the Great Barrier Reef. Proceedings of the Linnean Society of New South Wales 44: 213-239.

MURINA V. V. 1976. — [New abyssal species of echiurans from the Pacific and Atlantic Oceans]. Zoologicheskii Zhurnal 55: 837-844 (in Russian).

Murina V. V. 1978. - [New and rare echiurids of the family Bonelliidae]. Academia Nauk USSR. Trudy Instituta Okeanologii im P. P. Shirshova 113: 107-119 (in Russian).

NishiKaWA T. 1998. - Nomenclatural remarks on the family-group names of the Phylum Echiura. Proceedings of the Biological Society of Washington 111 (2): 249-256.

Saiz-Salinas J. I., Dean H. K. \& Cutler E. B. 2000. Echiura from Antarctic and adjacent waters. Polar Biology 23: 661-670.

SLUITER G. P. 1891. — Die Evertebraten aus der Sammlung des Königlichen naturwissenschlaftlichen Vereins in Niederländisch-Indien in Batavia. Zugleich eine Skizze der Fauna des Java-Meeres mit Beschreibung der neuen Arten. Natuurkunding Tijdschrift voor Nederlandisch-Indië 50: 102-123.

Sluiter G. P. 1902. — Die Sipunculiden und Echiuriden der Siboga-Expedition, nebst Zusammenstellung der überdies aus den indischen Archipel bekannten Arten. Siboga-Expeditie Monographie 25: 1-53.

STEPHEN A. C. \& EDMONDS S. J. 1972. - The Phyla Sipuncula and Echiura. The British Museum (Natural History), London, $508 \mathrm{p}$.

ZENKEVITCH L. A. 1958. - [The deep-sea echiurids of the North-Western part of the Pacific Ocean]. Trudy Instituta Okeanologii Akademii Nauk SSR 27: 192-203 (in Russian).

ZENKEVITCH L. A. 1964. - [New representatives of deep-sea echiurids Alomasoma belyaevi Zenk. sp. n. and Choanostoma filatovae n. sp. in the Pacific]. Zoologicheskii Zhurnal 43: 1863-1884 (in Russian).

ZENKEVITCH L. A. 1966. - The systematics and distribution of abyssal and hadal (ultraabyssal) Echiuroidea. Galathea Report 8: 175-184. 